\title{
Spectral and Magnetic Characterization of Copper(II)
}

\section{5-Bromosalicylates}

\author{
M. MELNÍK, ${ }^{a}$ Z. BAČÍK ${ }^{a}$ and H. SANDSTRÖM ${ }^{\text {b }}$ \\ ${ }^{a}$ Department of Inorganic Chemistry, Slovak Technical University, 88037 Bratislava, Czechoslovakia and \\ ${ }^{b}$ Department of Inorganic Chemistry, University of Helsinki, SF-00100 Helsinki, Finland
}

The compounds of copper(II) 5-bromosalicylate with pyridine, 3-picoline, ethylenediamine and dioxane, have been prepared and studied by magnetic susceptibility measurements between 77 and $294 \mathrm{~K}$, by infrared, electronic and EPR spectroscopy and by thermal analyses. All the compounds here reported are magnetically dilute, except $\mathrm{Cu}$ $(5 \mathrm{Brsal})_{2} \cdot \mathrm{C}_{4} \mathrm{H}_{8} \mathrm{O}_{2} \cdot \mathrm{H}_{2} \mathrm{O}$. For copper(II) 5-bromosalicylate trihydrate and its anhydrous form we propose a pseudo-octahedral coordination of $\mathrm{Cu}(\mathrm{II})$, and for the dioxan adduct a binuclear structure. For the pyridine, 3-picoline and ethylenediamine compounds, octahedral stereochemistry with different tetragonal distortions around $\mathrm{Cu}(\mathrm{II})$ is proposed.

The donor properties of substituted salicylic acids have not been studied so extensively as those of unsubstituted salicylic acid. Ernst and Menashi ${ }^{1}$ have studied the thermodynamic stability constants of some ferric substituted salicylates using the spectrophotometric method. They found that the stabilities depend on the nature of the substituent. The $\pi$-contribution in ferric salicylates was also investigated ${ }^{1}$ with the conclusion that the Fe(III) ion behaves as a $\pi$-donor in the ground state and $\pi$-electron acceptor in the excited state. The various complexes formed between $\mathrm{Fe}$ (III) ion and substituted salicylic acids in aqueous medium in the wider $\mathrm{pH}$ range $2-8$ have been investigated by Jahagirdar. ${ }^{2}$ The interactions of uranyl ion with some salicylates have been studied by potentiometric titrations. ${ }^{3}$ We have previously studied the spectral and magnetic properties of solid copper(II) 5-chlorosalicylates. ${ }^{4}$ Practically no work has been done on copper(II) compounds with 5-bromosalicylic acid in the solid state. The present work deals with some copper(II) 5-bromosalicylates: the trihydrate of copper(II) 5-bromosalicylate, its anhydrous form, and pyridine, 3-picoline, ethylenediamine and dioxane adducts have been prepared and the compounds characterized by elemental analyses and thermal, spectral and magnetic properties.

\section{EXPERIMENTAL}

Prepatative study. The trihydrate of copper(II) 5-bromosalicylate was prepared by reaction of a solution of the sodium salt of 5-bromosalicylic acid ( $\mathrm{pH}$ adjusted to 4.5-5.0 with free acid) and an aqueous solution of copper(II) sulfate in the molar ratio $2: 1$. The green product that precipitated after a few minutes was isolated, washed with water and dried at room temperature. The anhydrous copper(II) 5-bromosalicylate was obtained by drying over phosphorus pentaoxide for about $8 \mathrm{~h}$ at $105{ }^{\circ} \mathrm{C}$. The brown $\mathrm{Cu}(5 \mathrm{Brsal})_{2}, \quad\left(5 \mathrm{Brsal}=5-\mathrm{BrC}_{6} \mathrm{H}_{3}\right.$ $\mathrm{OHCOO}^{-}$) was found to be non-hygroscopic.

The two isomeric forms of $\mathrm{Cu}(5 \mathrm{Brsal})_{2} \mathrm{py}_{2}$, (py $=$ pyridine), as well as tris(pyridine)copper(II) 5-bromosalicylate were prepared as described previously ${ }^{5}$ (Scheme 1).

The grey-blue $\mathrm{Cu}(5 \mathrm{Brsal})_{2}(3-\text { pic })_{2},(3$-pic $=3$-picoline), was prepared by a heterogeneous reaction between trihydrate of copper(II) 5-bromosalicylate and 3-picoline. The powdered sample of $\mathrm{Cu}$ $(5 \mathrm{Brsal})_{2} \cdot 3 \mathrm{H}_{2} \mathrm{O}$ was left in an evacuated desiccator over 3-picoline for a few hours. The final compounds were dried at room temperature.

The violet-blue $\mathrm{Cu}(5 \mathrm{Brsal})_{2}(\mathrm{en})_{2.5}$, $(\mathrm{en}=$ ethylenediamine), was formed by a heterogeneous reaction between $\mathrm{Cu}(5 \mathrm{Brsal})_{2} \cdot 3 \mathrm{H}_{2} \mathrm{O}$ and ethylenediamine; the procedure was the same as for $\mathrm{Cu}(5 \mathrm{Brsal})_{2}$ (3-pic) ${ }_{2}$. 


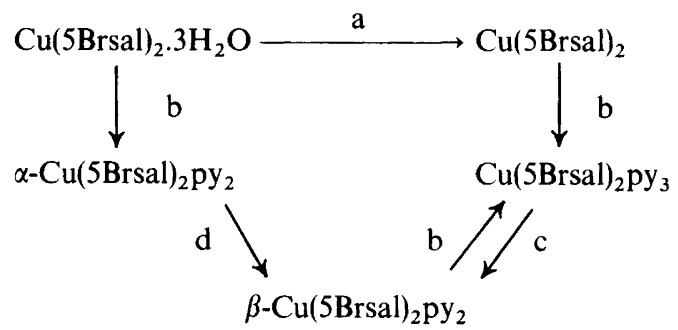

Scheme 1. a, at $105^{\circ} \mathrm{C}$; b, over pyridine; c, at $60{ }^{\circ} \mathrm{C}$; $\mathrm{d}$, at $80{ }^{\circ} \mathrm{C}$.

Green $\mathrm{Cu}(5 \mathrm{Brsal})_{2} \cdot \mathrm{C}_{4} \mathrm{H}_{8} \mathrm{O}_{2} \cdot \mathrm{H}_{2} \mathrm{O}$ was observed after trihydrate of copper(II) 5-bromosalicylate was kept over 1,4-dioxane in an evacuated desiccator for $48 \mathrm{~h}$.

Analytical data of the compounds are given in Table 1.

Thermal studies. The thermal decomposition was studied by means of a derivatograph (MOM Budapest). The measurements were made as previously described, ${ }^{6}$ in air atmosphere.

Spectral studies. IR spectra were measured in the region $400-3600 \mathrm{~cm}^{-1}$ with a UR 10 spectrophotometer and electronic spectra in the region 10-28 kK with a Perkin-Elmer 450 spectrophotometer. The Nujol suspension technique was used in both cases. EPR spectra of the powdered samples were run on a Varian Model E 4 spectrometer at room and liquid nitrogen temperatures.

Magnetic susceptibility measurements. Magnetic susceptibility measurements for the compounds were obtained over the temperature range 77-294 $\mathrm{K}$ by the Gouy method with mercury tetrathiocyanatocobaltate(II) as calibrant. ${ }^{7}$ Samples were finely ground powders. The effective absence of ferromagnetic impurities was indicated by the invariance of the observed susceptibilities to the field strength of the electromagnet $(2000-10000$ G). Diamagnetic corrections were calculated from Pascal's constants. ${ }^{8}$ The effective magnetic moments were calculated from the expression $\mu_{\text {eff }}=2.83$ $\left(\chi_{\mathrm{M}}^{\prime} \times \mathrm{T}\right)^{1 / 2}$.

\section{RESULTS AND DISCUSSION}

The thermal analyses of the copper(II) 5-bromosalicylate trihydrate indicate the presence of two types of differently bonded $\mathrm{H}_{2} \mathrm{O}$ molecules. In the temperature range $90-125^{\circ} \mathrm{C}$ the first two water molecules were liberated in one step (experimental $6.5 \%$, theoretical $6.54 \%$ ), which gave an endothermic peak in the DTA curve at that temperature. The third water molecule is given off at $140{ }^{\circ} \mathrm{C}$. Above this temperature the oxidation of the volatile organic product takes place, heat being emitted in the strong exothermic peak at $340{ }^{\circ} \mathrm{C}$ with a shoulder at about $420{ }^{\circ} \mathrm{C}$. The final level obtained at $660{ }^{\circ} \mathrm{C}$ corresponds to formation of $\mathrm{CuO}$.

The $\mathrm{Cu}(5 \mathrm{Brsal})_{2} \cdot \mathrm{C}_{4} \mathrm{H}_{8} \mathrm{O}_{2} \cdot \mathrm{H}_{2} \mathrm{O}$ is stable until $60{ }^{\circ} \mathrm{C}$, appearing on the $\mathrm{TG}$ curve as a plateau. Above this temperature, the elimination of the neutral ligand begins. At $170{ }^{\circ} \mathrm{C}$ the TG curve shows a break corresponding to the loss of $\mathrm{H}_{2} \mathrm{O}$ and the dioxane molecule (theoretical weight loss $17.7 \%$, experimental $\sim 18.5 \%$ ). Above $170{ }^{\circ} \mathrm{C}$ the decomposition accelerates rapidly to give at $660{ }^{\circ} \mathrm{C}$ copper oxide. On the DTA curve there are three endothermic peaks whose maxima are, respectively, at 100,170 and $250{ }^{\circ} \mathrm{C}$. A strongly exothermic double peak at about $360{ }^{\circ} \mathrm{C}$ represents an oxidation-reduction reaction.

The initial temperature of decomposition is $70{ }^{\circ} \mathrm{C}$ for $\mathrm{Cu}(5 \mathrm{Brsal})_{2} \mathrm{py}_{3}$. In the temperature range $70-105{ }^{\circ} \mathrm{C}$ the compound loses one molecule pyridine in one step (experimental $\sim 10 \%$; theo-

Table 1. Elemental analyses of copper(II) 5-bromosalicylates.

\begin{tabular}{lrlllllll}
\hline Compound & \multicolumn{2}{c}{ Calc. $(\%)$} & \multicolumn{5}{c}{ Found $(\%)$} & \\
& \multicolumn{1}{c}{$\mathrm{Cu}$} & $\mathrm{C}$ & $\mathrm{H}$ & $\mathrm{N}$ & $\mathrm{Cu}$ & $\mathrm{C}$ & $\mathrm{H}$ & $\mathrm{N}$ \\
\hline $\mathrm{Cu}(5 \mathrm{Brsal})_{2} \cdot 3 \mathrm{H}_{2} \mathrm{O}$ & 11.59 & 30.58 & 2.30 & & 11.66 & 30.84 & 1.95 & \\
$\mathrm{Cu}(5 \mathrm{Brsal})_{2}$ & 12.89 & 33.49 & 1.24 & & 12.96 & 32.80 & 1.25 & \\
$\alpha-\mathrm{Cu}(5 \mathrm{Brsal})_{2} \mathrm{py}_{2}$ & 9.71 & 44.09 & 2.78 & 4.28 & 9.62 & 43.46 & 2.72 & 4.09 \\
$\beta-\mathrm{Cu}(5 \mathrm{Brsal})_{2} \mathrm{py}_{2}$ & & & & & 9.70 & 43.87 & 2.74 & 4.12 \\
$\mathrm{Cu}(5 \mathrm{Brsal})_{2} \mathrm{py}_{3}$ & 8.67 & 47.53 & 3.16 & 5.73 & 8.71 & 47.67 & 3.14 & 5.66 \\
$\mathrm{Cu}(5 \mathrm{Brsal})_{2}(3-\mathrm{pic})_{2}$ & 9.31 & 45.80 & 3.25 & 4.11 & 9.36 & 45.69 & 3.23 & 4.7 \\
$\mathrm{Cu}(5 \mathrm{Brsal})_{2}(\mathrm{en})_{2.5}$ & 9.83 & 35.34 & 4.37 & 10.84 & 9.76 & 34.92 & 4.18 & 11.0 \\
$\mathrm{Cu}(5 \mathrm{Brsal})_{2} \cdot \mathrm{C}_{4} \mathrm{H}_{8} \mathrm{O}_{2} \cdot \mathrm{H}_{2} \mathrm{O}$ & 10.56 & 35.93 & 3.02 & & 10.45 & 36.3 & 3.2 & \\
\hline
\end{tabular}


retical $10.8 \%$ ), displayed as an endothermic peak in the DTA curve at that temperature. At $180{ }^{\circ} \mathrm{C}$ the TG curve shows a pseudo pause corresponding to the loss of the half molecule of pyridine. There is an endothermic peak in the DTA curve at that temperature. The DTA curve also shows exothermic peaks at 260 and $470{ }^{\circ} \mathrm{C}$ with a shoulder at about $570{ }^{\circ} \mathrm{C}$. It is not possible to isolate $\mathrm{Cu}(5 \mathrm{Brsal})_{2}$ because it decomposes before complete elimination of the pyridine molecules.

Further information about the ligand coordination was obtained from IR data.

The IR spectrum of $\mathrm{Cu}(5 \mathrm{Brsal})_{2} \cdot 3 \mathrm{H}_{2} \mathrm{O}$ shows a wide absorption band at $\sim 3300 \mathrm{~cm}^{-1}$ which can be attributed to the antisymmetric and symmetric $\mathrm{OH}$ stretching modes of the water molecules. The width of the band shows that lattice-held water is present in the compound. The absorption bands at $1630 \mathrm{~cm}^{-1}$ and especially at $825 \mathrm{~cm}^{-1}$, on the other hand are probably due to bonded water molecules. No bands in these regions were found in the case of the anhydrous form. In the IR spectrum of the free 5-bromosalicylic acid there is an intense band due to the carboxyl group: $v_{\mathrm{a}}$ at $1668 \mathrm{~cm}^{-1}$ and $v_{\mathrm{s}}$ at $1300 \mathrm{~cm}^{-1}$. The anhydrous form has a splitting band at about 1680 and $1635 \mathrm{~cm}^{-1}$, which can be assigned to $v_{\mathrm{a}} \mathrm{COO}^{-}$. The antisymmetric $\mathrm{COO}^{-}$stretch absorbs at $1645 \mathrm{~cm}^{-1}$ in the case of trihydrate copper(II) 5-bromosalicylate. Locating the symmetric $\mathrm{COO}^{-}$stretch is very difficult because there is a wide band in the region $\sim 1400$ $\mathrm{cm}^{-1}$ where the bands are expected. The IR spectrum of $\mathrm{Cu}(5 \mathrm{Brsal})_{2} \cdot \mathrm{C}_{4} \mathrm{H}_{8} \mathrm{O}_{2} \cdot \mathrm{H}_{2} \mathrm{O}$ shows absorption bands at $3360,3210,1625$ and $820 \mathrm{~cm}^{-1}$ which can be attributed to the $\mathrm{H}_{2} \mathrm{O}$ molecule. The $v_{\mathrm{a}} \mathrm{COO}^{-}$was found at $1650 \mathrm{~cm}^{-1}$ and $v_{\mathrm{s}} \mathrm{COO}^{-}$at $1420 \mathrm{~cm}^{-1}$. Malherbe and Bernstein ${ }^{9}$ assigned the rocking and wagging modes of $A_{g}$ vibrations of pure 1,4-dioxane at 827 and $1127 \mathrm{~cm}^{-1}$, respectively. In the case of the dioxan adduct we found the bands at $880 \mathrm{~cm}^{-1}$ and at $1105 \mathrm{~cm}^{-1}$ and conclude that the dioxane is bonded to the $\mathrm{Cu}(\mathrm{II})$ ion.

The stretching vibration of $\mathrm{C}=\mathrm{N}$ in the pyridine ring ${ }^{10}$ appears at $1582 \mathrm{~cm}^{-1}$. In the pyridine and 3-picoline adducts of copper(II) 5-bromosalicylate the peak shifts to higher frequencies $\sim 1590 \mathrm{~cm}^{-1}$. This may suggest a bond formation between the $\mathrm{Cu}$ (II) and the ring nitrogen, as the dipolar contribution of $\mathrm{C}=\mathrm{N}^{+}$in the pyridine ring increases. ${ }^{10}$ The $v_{\mathrm{a}} \mathrm{COO}^{-}$of $\mathrm{Cu}(5 \mathrm{Brsal})_{2} \mathrm{~L}_{2} \quad(\mathrm{~L}=$ pyridine or $3-$ picoline) absorbs at about $\sim 1630 \mathrm{~cm}^{-1}$ and that
Table 2. Electronic spectral data $\left(v_{\max }(\mathrm{kK})\right)$.

\begin{tabular}{lll}
\hline Compound & Band I & Band II \\
\hline $\mathrm{Cu}(5 \mathrm{Brsal})_{2} .3 \mathrm{H}_{2} \mathrm{O}$ & 14.3 & 24 \\
$\mathrm{Cu}(5 \mathrm{Brsal})_{2}$ & 13.6 & 22 \\
$\alpha-\mathrm{Cu}(5 \mathrm{Brsal})_{2} \mathrm{py}_{2}$ & $17.0,14.1$ & - \\
$\beta-\mathrm{Cu}(5 \mathrm{Brsal})_{2} \mathrm{py}_{2}$ & $17.2,14.2$ & 23 \\
$\mathrm{Cu}(5 \mathrm{Brsal})_{2} \mathrm{py}_{3}$ & 15.6 & - \\
$\mathrm{Cu}(5 \mathrm{Brsal})_{2}(3-\mathrm{pic})_{2}$ & $17.0,14.3$ & 22.5 \\
$\mathrm{Cu}(5 \mathrm{Brsal})_{2} \mathrm{en}_{2.5}$ & 17.6 & 28.5 \\
$\mathrm{Cu}(5 \mathrm{Brsal})_{2} \mathrm{C}_{4} \mathrm{H}_{8} \mathrm{O}_{2} \cdot \mathrm{H}_{2} \mathrm{O}$ & 13.6 & 24 \\
\hline
\end{tabular}

Table 3. EPR data.

\begin{tabular}{llll}
\hline Compound & $g_{1}$ & $g_{u}$ & $g_{\mathrm{av}}$ \\
\hline $\mathrm{Cu}(5 \mathrm{Brsal})_{2} .3 \mathrm{H}_{2} \mathrm{O}$ & $2.06_{6}$ & $2.34_{9}$ & $2.17_{0}$ \\
& $\left(2.06_{3}\right.$ & $2.33_{9}$ & $\left.2.15_{8}\right)^{a}$ \\
$\mathrm{Cu}(5 \mathrm{Brsal})_{2}$ & $2.04_{1}$ & $2.38_{4}$ & $2.16_{0}$ \\
& & & $\left(2.06_{3}\right)^{a}$ \\
$\alpha-\mathrm{Cu}(5 \mathrm{Brsal})_{2} \mathrm{py}_{2}$ & $2.05_{5}$ & $2.27_{3}$ & $2.13_{0}$ \\
$\beta-\mathrm{Cu}(5 \mathrm{Brsal})_{2} \mathrm{py}_{2}$ & $2.04_{6}$ & $2.25_{2}$ & $2.11_{7}$ \\
$\mathrm{Cu}(5 \mathrm{Brsal})_{2} \mathrm{py}_{3}$ & $2.02_{8}$ & $2.24_{8}$ & $2.10_{3}$ \\
$\mathrm{Cu}(5 \mathrm{Brsal})_{2}(3-\mathrm{pic})_{2}$ & $2.05_{9}$ & $2.24_{3}$ & $2.12_{2}$ \\
$\mathrm{Cu}(5 \mathrm{Brsal})_{2} \mathrm{en}_{2.5}$ & & & $2.10_{2}$ \\
\hline
\end{tabular}

${ }^{a}$ At liquid nitrogen temperature.

of the tri(pyridine) adduct at 1665 and $1620 \mathrm{~cm}^{-1}$.

The IR spectrum of ethylenediamine ${ }^{11}$ shows two absorption peaks in the amino region, one at about $3510 \mathrm{~cm}^{-1}$ and the other at about $1595 \mathrm{~cm}^{-1}$; both represent free amino groups. In the spectrum of $\mathrm{Cu}(5 \mathrm{Brsal})_{2} \mathrm{en}_{2.5}$ these peaks are located at about 3295,3130 and $1575 \mathrm{~cm}^{-1}$, and are probably due to bonded amino groups. ${ }^{12}$ The $v_{\mathrm{a}} \mathrm{COO}^{-}$absorbs at about $1660 \mathrm{~cm}^{-1}$ and $v_{\mathrm{s}} \mathrm{COO}^{-}$at $1440 \mathrm{~cm}^{-1}$ as a splitting band.

Electronic absorption spectra (Table 2) of copper(II) 5-bromosalicylate trihydrate and its anhydrous form exhibit a broad band with a maximum at $\sim 14 \mathrm{kK}$ (band I) and a shoulder at $\sim 23 \mathrm{kK}$ (band II). Band I can be assigned to $d-d$ transitions and band II to a charge-transfer. Similar spectra were observed for $\mathrm{Cu}(5 \mathrm{Brsal})_{2} \mathrm{py}_{3}$ and $\mathrm{Cu}(5 \mathrm{Brsal})_{2} \mathrm{en}_{2.5}$. In the compounds of composition $\mathrm{Cu}(5 \mathrm{Brsal})_{2} \mathrm{~L}_{2}$ ( $\mathrm{L}=$ pyridine or 3-picoline), a pair of bands were observed instead of a single $d-d$ band. This splitting in the band may be considered to result from distortion of octahedral structure. Similar splitting has been observed by Kettle and Pioli. ${ }^{13}$ 
Table 4. Magnetic data.

\begin{tabular}{|c|c|c|c|c|c|c|c|}
\hline$T, \mathrm{~K}$ & $\chi g \times 10^{6}$ & $\chi_{M}^{\prime} \times 10^{6}$ & $\mu_{\text {eff }}$, B.M. & $T, \mathbf{K}$ & $\chi g \times 10^{6}$ & $\chi_{M}^{\prime} \times 10^{6}$ & $\mu_{\mathrm{eff}}$, B.M. \\
\hline \multicolumn{4}{|c|}{$\begin{array}{l}\mathrm{Cu}(5 \mathrm{Brsal})_{2} .3 \mathrm{H}_{2} \mathrm{O} \\
\left(-\Delta \times 10^{6}=255\right)\end{array}$} & \multicolumn{4}{|c|}{$\begin{array}{l}\mathrm{Cu}(5 \mathrm{Brsal})_{2} \\
\left(-\Delta \times 10^{6}=216\right)\end{array}$} \\
\hline 77 & 12.33 & 7030 & 2.08 & 77 & 9.53 & 4938 & 1.74 \\
\hline 100 & 9.55 & 5503 & 2.09 & 100 & 8.88 & 4616 & 1.89 \\
\hline 112 & 8.32 & 4827 & 2.07 & 121 & 7.04 & 3704 & 1.89 \\
\hline 125 & 7.45 & 4349 & 2.08 & 133 & 6.20 & 3288 & 1.87 \\
\hline 138 & 6.70 & 3937 & 2.08 & 146 & 5.76 & 3070 & 1.89 \\
\hline 151 & 6.11 & 3612 & 2.08 & 159 & 5.35 & 2867 & 1.91 \\
\hline 164 & 5.47 & 3261 & 2.07 & 178 & 5.02 & 2703 & 1.95 \\
\hline 177 & 5.01 & 3008 & 2.06 & 192 & 4.55 & 2470 & 1.95 \\
\hline 190 & 4.69 & 2832 & 2.06 & 205 & 4.36 & 2376 & 1.97 \\
\hline 203 & 4.38 & 2662 & 2.06 & 218 & 4.15 & 2272 & 1.98 \\
\hline 216 & 4.14 & 2530 & 2.08 & 231 & 3.93 & 2163 & 1.99 \\
\hline 229 & 3.92 & 2409 & 2.09 & 245 & 3.75 & 2074 & 2.00 \\
\hline 245 & 3.64 & 2255 & 2.09 & 260 & 3.56 & 1980 & 2.02 \\
\hline 259 & 3.34 & 2090 & 2.08 & 275 & 3.39 & 1885 & 2.03 \\
\hline 272 & 3.09 & 1953 & 2.07 & 285 & 3.25 & 1826 & 2.04 \\
\hline 285 & 2.94 & 1870 & 2.07 & 294 & 3.19 & 1796 & 2.05 \\
\hline 294 & 2.85 & 1821 & 2.07 & & & & \\
\hline \multicolumn{4}{|c|}{$\begin{array}{l}\alpha-\mathrm{Cu}(5 \mathrm{Brsal})_{2} \mathrm{py}_{2} \\
\left(-\Delta \times 10^{6}=326\right)\end{array}$} & \multicolumn{4}{|c|}{$\begin{array}{l}\mathrm{Cu}(5 \mathrm{Brsal})_{2} \mathrm{py}_{3} \\
\left(-\Delta \times 10^{6}=381\right)\end{array}$} \\
\hline 93 & 7.23 & 5051 & 1.94 & & 5.74 & 4591 & 1.85 \\
\hline 113 & 5.80 & 4117 & 1.93 & & 4.65 & 3788 & 1.85 \\
\hline 133 & 4.88 & 3510 & 1.93 & & 3.81 & 3178 & 1.84 \\
\hline 153 & 4.14 & 3036 & 1.93 & & 3.33 & 2822 & 1.86 \\
\hline 173 & 3.62 & 2691 & 1.93 & & 2.88 & 2489 & 1.86 \\
\hline 193 & 2.96 & 2260 & 1.87 & & 2.55 & 2244 & 1.86 \\
\hline 213 & 2.64 & 2050 & 1.87 & & 2.25 & 2030 & 1.86 \\
\hline 233 & 2.36 & 1872 & 1.87 & & 2.01 & 1854 & 1.86 \\
\hline 253 & 2.13 & 1725 & 1.87 & & 1.78 & 1689 & 1.85 \\
\hline 273 & 1.95 & 1600 & 1.87 & & 1.62 & 1568 & 1.86 \\
\hline 293 & 1.75 & 1472 & 1.86 & & 1.49 & 1476 & 1.86 \\
\hline \multicolumn{4}{|c|}{$\begin{array}{l}\mathrm{Cu}(5 \mathrm{Bral})_{2}(3-\mathrm{pic})_{2} \\
\left(-\Delta \times 10^{6}=350\right)\end{array}$} & \multicolumn{4}{|c|}{$\begin{array}{l}\mathrm{Cu}(5 \mathrm{Brsal})_{2} \mathrm{en}_{2.5} \\
\left(-\Delta \times 10^{6}=332\right)\end{array}$} \\
\hline 93 & 6.99 & 4678 & 1.87 & & 6.36 & 4444 & 1.82 \\
\hline 113 & 5.67 & 3858 & 1.87 & & 5.15 & 3656 & 1.82 \\
\hline 133 & 4.79 & 3318 & 1.88 & & 4.26 & 3082 & 1.81 \\
\hline 153 & 4.14 & 2914 & 1.89 & & 3.77 & 2766 & 1.84 \\
\hline 173 & 3.64 & 2605 & 1.90 & & 3.26 & 2440 & 1.84 \\
\hline 193 & 3.22 & 2344 & 1.90 & & 2.88 & 2190 & 1.84 \\
\hline 213 & 2.85 & 2116 & 1.90 & & 2.41 & 1982 & 1.84 \\
\hline 233 & 2.52 & 1912 & 1.89 & & 2.29 & 1815 & 1.84 \\
\hline 253 & 2.09 & 1780 & 1.90 & & 2.38 & 1675 & 1.84 \\
\hline 273 & 1.91 & 1650 & 1.90 & & 1.89 & 1557 & 1.84 \\
\hline 293 & 1.72 & 1521 & 1.89 & & 1.72 & 1442 & 1.84 \\
\hline
\end{tabular}


The well-resolved EPR spectra obtained for the polycrystalline samples at room temperature show absorption bands of axial type, ${ }^{14}$ except $\mathrm{Cu}(5 \mathrm{Brsal})_{2} \mathrm{en}_{2.5}$ which has an isotropic spectrum (Table 3). At liquid nitrogen temperature, copper(II) 5-bromosalicylate trihydrate has a clearly anisotropic spectrum, but the anhydrous form exhibits an isotropic spectrum (Table 3). In the case of $\mathrm{Cu}(5 \mathrm{Brsal})_{2} \mathrm{py}_{3}$, the resonance of $g_{\|}$is split into hyperfine lines with a value of $A_{\|}=118$ Oe. The EPR spectra of all the compounds are typical of an effective spin $S=1 / 2$.

Study of the magnetic properties of the compounds showed all except $\mathrm{Cu}(5 \mathrm{Brsal})_{2} \cdot \mathrm{C}_{4} \mathrm{H}_{8} \mathrm{O}_{2} \cdot \mathrm{H}_{2} \mathrm{O}$ to be magnetically diluted copper(II) compounds (Table 4). Variable-temperature magnetic susceptibility data obey the Curie-Weiss law, $\chi_{M}^{\prime}=C /(T-\theta)$. The best parameter values of the Curie (C) and Weiss constant $(\theta)$ are given in Table 5 . From the value of $\theta$, it is evident that in $\mathrm{Cu}(5 \mathrm{Brsal})_{2}$ there is an antiferromagnetic super-exchange interaction between the $\mathrm{Cu}(\mathrm{II})$ atoms in the polynuclear structure, weaker than in the case ${ }^{4}$ of $\mathrm{Cu}(5 \mathrm{Clsal})_{2}$, how-

Table 5. The values of the $C$ and $\theta$ constants.

\begin{tabular}{llc}
\hline Compound & $\begin{array}{l}C, \text { c.g.s.u.kmol } \\
( \pm 0.003)\end{array}$ & $\begin{array}{l}\theta 1 \mathrm{~K} \\
( \pm 0.2)\end{array}$ \\
\hline $\mathrm{Cu}(5 \mathrm{Brsal})_{2} .3 \mathrm{H}_{3} \mathrm{O}$ & 0.534 & 2.2 \\
$\mathrm{Cu}(5 \mathrm{Brsal})_{2}$ & 0.582 & -37 \\
$\alpha-\mathrm{Cu}(5 \mathrm{Brsal})_{2} \mathrm{py}_{2}$ & 0.412 & 14.3 \\
$\mathrm{Cu}(5 \mathrm{Brsal})_{2} \mathrm{py}_{3}$ & 0.432 & -0.1 \\
$\mathrm{Cu}(5 \mathrm{Brsal})_{2}(3-\mathrm{pic})_{2}$ & 0.450 & -1.5 \\
$\mathrm{Cu}(5 \mathrm{Brsal})_{2} \mathrm{en}_{2.5}$ & 0.430 & -1.6 \\
\hline
\end{tabular}

Table 6. Magnetic data of $\mathrm{Cu}(5 \mathrm{Brsal})_{2} \cdot \mathrm{C}_{4} \mathrm{H}_{8} \mathrm{O}_{2} \cdot \mathrm{H}_{2} \mathrm{O}$, $\left(-\Delta \times 10^{6}=273\right)$.

\begin{tabular}{rlll}
\hline$T, \mathrm{~K}$ & $\chi \mathrm{g} \times 10^{6}$ & $\chi_{\mathrm{M}}^{\prime} \times 10^{6}$ & $\mu_{\mathrm{eff}}, \mathrm{B} . \mathrm{M}$. \\
\hline 93 & 0.60 & 634 & 0.69 \\
113 & 0.69 & 690 & 0.79 \\
133 & 0.70 & 695 & 0.86 \\
153 & 0.83 & 770 & 0.97 \\
173 & 0.90 & 815 & 1.06 \\
193 & 0.96 & 853 & 1.15 \\
213 & 0.93 & 866 & 1.23 \\
233 & 1.02 & 887 & 1.28 \\
253 & 1.06 & 910 & 1.36 \\
273 & 1.12 & 946 & 1.44 \\
293 & 1.13 & 953 & 1.50 \\
\hline
\end{tabular}

Acta Chem. Scand. A 33 (1979) No. 10 ever. There is a small ferromagnetic interaction in $\alpha-\mathrm{Cu}(5 \mathrm{Brsal})_{2} \mathrm{py}_{2}$, on the other hand. The increase in magnetic moment with decrease in temperature for $\alpha-\mathrm{Cu}(5 \mathrm{Brsal})_{2} \mathrm{py}_{2}$ is small but significant and probably, as in $\mathrm{Cu}(5 \mathrm{Clsal})_{2} \mathrm{py}_{2}$, indicates that the singlet level lies appreciably above the ground state. ${ }^{4}$ In other cases, (Table 5), the Weiss constant is less than $5 \mathrm{~K}$, the interaction is very small and does not seriously affect the ground state. ${ }^{8}$

In summary, tetragonal coordination of $\mathrm{Cu}(\mathrm{II})$ may be proposed for trihydrate copper(II) 5-bromosalicylate and its anhydrous form. The pseudo-octahedral coordination is proposed for copper(II) 5bromosalicylates with 3-picoline or ethylenediamine. The two isomers of $\mathrm{Cu}(5 \mathrm{Brsal})_{2} \mathrm{py}_{2}$ were assumed $^{5}$ to possess octahedral stereochemistry with different tetragonal distortions around the $\mathrm{Cu}(\mathrm{II})$.

The magnetic properties of $\mathrm{Cu}(5 \mathrm{Brsal})_{2} \cdot \mathrm{C}_{4} \mathrm{H}_{8} \mathrm{O}_{2}$.$\mathrm{H}_{2} \mathrm{O}$ are surprisingly similar to those observed for copper(II) acetate monohydrate ${ }^{15}$ (Table 6). The temperature variation of the molar susceptibility may be described by the Van Vleck equation for exchange-coupled dimers. ${ }^{16}$ A Fortran V program was written and used to interpret the data with a Univac 1108 computer. The TIP term was set equal to $60 \times 10^{-6} \mathrm{cgs}$ units. The best fit parameters were found to be $g=2.20( \pm 0.03) ;-2 J=333 \mathrm{~cm}^{-1}$ $( \pm 30)$.

At room temperature the EPR spectrum of the dioxan adduct showed well-resolved absorption bands belonging to the triplet state. ${ }^{17}$ The spinHamiltonian for triplet state dimeric copper(II) compounds is given by

$$
H=g \beta H S+D\left(S_{z}^{2}-1 / 3 S(S+1)\right)
$$

where $S=1$ and $D$, the zero-field parameter, and other symbols have their usual meanings. ${ }^{17}$ The observed values of $g_{1}=2.09_{6}, g_{11}=2.38_{6}$ and $|D|=$ $0.355 \mathrm{~cm}^{-1}$ are very close to those reported for copper(II) acetate monohydrate. On the basis of spectral and magnetic properties a binuclear structure may be proposed for $\mathrm{Cu}(5 \mathrm{Brsal})_{2} \cdot \mathrm{C}_{4} \mathrm{H}_{8} \mathrm{O}_{2} \cdot \mathrm{H}_{2} \mathrm{O}$.

Acknowledgements. The authors are grateful to Mr. M. Väisänen, $\mathrm{Ph}$. M., for the least-squares program. The calculations are made on the Univac 1108 computer at the Helsinki University of Technology. 


\section{REFERENCES}

1. Ernst, Z. L. and Menashi, J. Trans. Faraday Soc. 59 (1963) 2838.

2. Jahagirdar, D. V. J. Inorg. Nucl. Chem. 36 (1974) 2388.

3. Jahagirdar, D. V. and Khanolkar, D. D. $J$. Inorg. Nucl. Chem. 35 (1973) 921.

4. Melnik, M. J. Inorg. Nucl. Chem. 40 (1978) 463.

5. Melnik, N. and Bačik, Z. Proc. 7th Conf. Coord. Chem., Smolenice-Bratislava, Czechoslovakia 1978, p. 159.

6. Melnik, M. Finn. Chem. Lett. (1974) 189.

7. Figgis, B. N. and Nyholm, R. S. J. Chem. Soc. (1958) 4190.

8. Earnshaw, A. Introduction to Magnetochemistry, Academic, London 1968.

9. Malherbe, E. F. and Bernstein, H. J. J. Am. Chem. Soc. 74 (1952) 4408.

10. Kidani, Y., Noji, M. and Koike, H. Bull. Chem. Soc. Jpn. 48 (1975) 239.

11. Gordon, G. and Birdwhistell, R. K. J. Am. Chem. Soc. 81 (1959) 3567.

12. Kirschner, S. J. Am. Chem. Soc. 78 (1956) 2372.

13. Kettle, S. F. A. and Pioli, A. J. P. J. Chem. Soc. $A$ (1968) 1243.

14. Hathaway, B. J. and Billing, D. E. Coord. Chem. Rev. 3 (1970) 143.

15. Figgis, B. N. and Martin, R. L. J. Chem. Soc. (1956) 3837.

16. Van Vleck, J. H. Theory of Electric and Magnetic Susceptibilities, Oxford University Press, London and New York 1932, Chapter 9.

17. Bleaney, B. and Bowers, K. D. Proc. R. Soc. London A 214 (1952) 451.

Received May 30, 1979. 